\title{
PERAN KEPALA MADRASAH DALAM MENINGKATKAN ETOS KERJA GURU
}

\author{
Ahmad Syukri ${ }^{1}$, Nuzuar ${ }^{2}$, Idi Warsah ${ }^{3}$ \\ Program Pascasarjana, IAIN Curup ${ }^{1,2,3}$ \\ Syukri2019@gmail.com
}

\begin{abstract}
ABSTRAK
Tujuan penelitian ini untuk mengetahui peran kepala sekolah dalam meningkatkan kinerja guru. Penelitian menggunakan pendekatan penelitian lapangan (field research). Hasil penelitian, kepala madrasah selalu melakukan pengawasan atau supervisi langsung dengan cara keliling kelas untuk melihat guru. Selain melakukan supervisi pengajaran terhadap guru kepala madrasah juga berperan dalam proses pelaksanaan monitoring atau evaluasi terhadap hasil kerja semua staf yang ada di madrasah termasuk juga guru, kepala madrasah berusaha mempengaruhi para guru dan karyawan untuk menimbulkan semangat terhadap pekerjaan dan komitmen terhadap sasaran tugas. Simpulan dari penelitian ini adalah kepala madrasah berperan aktif dalam upaya meningkatkan etos kerja guru yaitu dengan menjalin hubungan yang harmonis terhadap sesama pengajar (para guru), memberikan kesejahteraan kepada para guru yang memadahi, mengkontrol dan mengevaluasi guru dalam menjalankan tugas mereka sehingga dapat merubah pola pikir dalam membangun karakter guru, sehingga para guru turut membangun madrasah menjadi terdepan sesuai dengan visi dan misinya.
\end{abstract}

Kata Kunci: Peran Kepala Sekolah, Etos Kerja Guru

\begin{abstract}
The purpose of this study was to determine the role of the principal in improving teacher performance. Research uses a field research approach (field research). The results of the study, the headmaster always supervises or supervises by going around the classroom to see the teacher. In addition to supervising the teaching of the madrasah head teacher also plays a role in the process of monitoring or evaluating the work of all staff in the madrasah including the teacher, the madrasa head tries to influence teachers and employees to encourage enthusiasm for work and commitment to the task objectives. The conclusion of this research is the madrasa head plays an active role in efforts to improve the work ethic of teachers, namely by establishing harmonious relationships with fellow teachers (teachers), providing welfare to teachers who accommodate, control and evaluate teachers in carrying out their tasks so that they can change mindsets in building the character of the teacher, so that the teachers helped build the madrasas to be the foremost in accordance with their vision and mission.
\end{abstract}

Keywords: The Principal's Role, Teacher's Work Ethic 


\section{PENDAHULUAN}

Kepala Madrasah adalah pemimpin pendidikan yang mempunyai peran sangat besar dalam mengembangkan mutu sumber daya guru di sekolah. Oleh sebab itu, kepala sekolah harus yakin bahwa anggota sekolahnya memerlukan standar, harapan dan kinerja bermutu tinggi. Selain itu, kepala Madrasah harus yakin bahwa visi sekolah harus menekankan standar pelajaran yang tinggi. Ketercapaian tujuan pendidikan sangat bergantung pada kecakapan dan kebijaksanaan kepala sekolah sebagai salah satu pemimpin pendidikan.

Berbagai gaya kepemimpinan akan mewarnai perilaku seorang pemimpin dalam menjalankan tugasnya. Bagaimanapun gaya kepemimpinan seseorang tentunya akan diarahkan untuk kepentingan bersama yaitu kepentingan anggota dan organisasi. Dalam sebuah lembaga pendidikan, salah satu elemen yang berperan penting sebagai agen perubahan adalah pemimpin yang memimpin lembaga tersebut. Hal ini karena pemimpinlah yang menjadi "pengemudi" ke mana lembaga pendidikan yang pimpinnya itu akan dibawa. Peran key position kemajuan dan perkembangan tidak keliru dialamatkan kepada kepemimpinan kepala madrasah. Begitu pentingnya sebuah kepemimpinan dalam kehidupan manusia, diwajibkan setiap individu untuk tunduk kepada Allah dan rasul-Nya serta ulil amri

Dalam memimpin suatu organisasi Madrasah, kepala Madrasah dapat menekankan salah satu bentuk atau model kepemimpinan yang ada. Model atau gaya kepemimpinan mana yang paling sesuai masih menjadi pertanyaan. Keberadaan madrasah sebagai organisasi pendidikan akan berpengaruh terhadap keefektifan model kepemimpinan kepala madrasah yang diterapkan. Karena madrasah adalah lembaga yang bersifat kompleks dan unik. Bersifat kompleks karena madrasah sebagai organisasi di dalamnya terdapat berbagai dimensi yang satu sama lain saling berkaitan dan saling menentukan. Kepemimpinan Kepala Madrasah sangat menentukan dalam memperlancar kegiatan belajar mengajar (KBM). Peranannya bukan hanya menguasai teori-teori kepemimpinan, lebih dari itu seorang Kepala Madrasah harus bisa mengimplementasikan kemampuannya dalam aplikasi teori secara nyata. Untuk itu seorang Kepala Madrasah dituntut untuk memiliki ilmu Pendidikan secara menyeluruh

Dalam hal ini, pengembangan SDM merupakan proses peningkatan kemampuan manusia agar mampu melaksanakan pilihan-pilihan. Pengertian ini memusatkan perhatian pada pemerataan dalam peningkatan kemampuan manusia dan pemanfaatan kemampan itu (Mulyasa, 2005).

Seorang kepala Madrasah menduduki jabatannya karena ditetapkan dan diangkat oleh atasan (Yayasan) (Soewadji, 1988).Fungsi kepala Madrasah yang berhubungan dengan guru di sebuah Madrasah adalah memahami kondisi guru dan karyawan. Dalam menjalankan tugas tersebut ia tidak bisa mewujudkan tujuannya apabila kondisi kerja para guru tidak tertata dengan baik.Sebagai pemimpin pendidikan, kepala Madrasah menghadapi tanggungjawab yang berat, 
untuk itu ia harus memiliki persiapan memadai. Ia hendaknya belajar bagaimana mendelegir wewenang dan tanggungjawab sehingga ia dapat memusatkan perhatiannya pada usaha-usaha pembinaan program pengajaran (Hendiyat, 1984).

Dalam kerangka inilah dirasa perlunya peningkatan kemampuan kepala Madrasah secara profesional untuk mensukseskan program-program pemerintah yang digulirkan berkaitan dengan peningkatan mutu pendidikan. Untuk maksud, maka kepala sekolah harus tahu apa yang harus dicapai (visi) dan bagaimana mencapainya (misi). Kepala Madrasah harus memiliki karakter yang menunjukkan integritasnya. Segala bentuk kegiatan sekolah selalu diarahkan padapeningkatan profesionalisme tenaga pendidik dan kependidikan untuk mengembangkanmutu pendidikan agar dapat berkembang dan maju sesuai dengan kebutuhan pembangunan dan perkembangan zaman.

Kualitas sumberdaya manusia adalah kunci utama dalam pembangunan sebuah bangsa. Bangsa Indonesia tertinggal dengan bangsa lain karena lebih membanggakan sumber daya alamnya dari pada sumber daya manusia. Upaya peningkatan kualitas pendidikan di Indonesia menunjukkan kesadaran atas pentingnya kualitas sumberdaya manusia itu bagi pembangunan bangsa.

Dalam kaitannya dengan kegiatan pendidikan unsur yang sangat penting menentukan ketercapaian tujuan adalah sumberdaya guru. Guru merupakan komponen yang layak mendapatkan perhatian karena baik ditinjau dari segi posisi yang ditempati dalam struktur organisasi pendidikan maupun dilihat dari tugas dan kewajiban yang diemban, guru merupakan pelaksana terdepan yang dapat menentukan dan mewarnai proses belajar mengajar serta kualitas pendidikan umumnya.

\section{METODE PENELITIAN}

Penelitian menggunakan pendekatan penelitian lapangan (field research) dimana untuk memperoleh data yang akurat serta obyektif, maka penulis datang langsung ke lokasi penelitian. Sumber data meliputi; data primer dan sekunder. Dalam penelitian ini, penulis menggunakan beberapa metode dalam pengumpulan data, yaitu: 1) interview/wawancara, metode ini untuk mendapatkan data dari kepala Madrasah yang sesungguhnya tentang peran kepemimpinan kepala Madrasah terhadap guru pendidikan agama Islam. Untuk wawancara terhadap guru mengenai pelaksanaan dalam peningkatan guru pendidikan agama Islam (sebagai jawaban dari kepala Madrasah, tentang pelaksanaan untuk guru, 2) metode observasi, dalam hal ini yang diobservasi adalah mengenai pelaksanaan proses sikap guru bidang studi pendidikan agama Islam di Madrasah, 3) metode demonstrasi, adapun metode ini digunakan penulis untuk memperoleh data-data tentang dokumentasi seperti: agenda kepala Madrasah, catatan kegiatan kepala Madrasah dan guru dan lain-lain. 
Analisis data dalam penelitian kualitatif menurut Matthew B. Milles terdiri dari tiga alur kegiatan yang terjadi secara bersamaan, yaitu : Reduksi data, penyajian data, dan verifikasi atau penarikan kesimpulan.

Reduksi Data. Analisis data dimulai beriringan dengan proses pengumpulan data dilanjutkan dengan pengkajian dan penilaian data dengan tetap memperlihatkan prinsip keabsahan data, dalam rangka memperoleh data yang benar-benar berguna bagi penelitian. Di sini data yang telah dikumpulkan direduksi dengan melakukan penyederhanaan pengabstrakan, pemilahan dan pemetaan (persamaan dan perbedaan) sesuai dengan fokus penelitian secara sistematis dan integral. Reduksi data ini berlangsung terus menerus selama penelitian berlangsung hingga sampai pada penarikan suatu kesimpulan

Penyajian Data. Penyajian data dimaksud menampilkan berbagai data yang telah diperoleh sebagai sebuah informasi yang lebih sederhana, selektif dan memudahkan untuk memaknainya. Penyajian data dalam penelitian ini disusun secara naratif, bentuk table dan gambar, yang dibuat setelah pengumpulan dan reduksi data dengan didasarkan pada kontek dan teori yang telah dibangun untuk mengungkapkan fenomena dan noumena yang terjadi sesuai dengan fokus penelitian.

Penarikan Kesimpulan. Penarikan kesimpulan merupakan akhir dari rangkaian data setelah sebelumnya dilakukan reduksi dan penyajian data, yang menjelaskan alur sebab akibat suatu fenomena dan noumena terjadi. Dalam proses ini selalu disertai dengan upaya verifikasi (pemikiran kembali), sehingga disaat ditemukan ketidaksesuaian antara fenomena, noumena, data, dengan konsep dan teori yang dibangun, maka peneliti kembali melakukan pengumpulan data, atau reduksi data atau perbaikan dalam penyajian data kembali, sehingga dapat diperoleh kesimpulan yang benar-benar utuh. Dalam penarikan kesimpulan peneliti menggunakan teori yang dipakai sebagai kerangka pikir penelitian.

\section{HASIL PENELITIAN}

\section{Peran Kepala Madrasah dalam Meningkatkan Etos Kerja Guru}

Adapun berkaitan dengan peran kepala madrasah dalam melakukan pengawasan atau supervisi pendidikan dalam meningkatkan Etos Kerja guru diMTs Bahrul Ulum Rantau jaya ini, berikut hasil wawancara peneliti dengan kepala Madrasah yakni Bapak Supriadi S.Pd.I., M.Pdsebagai berikut:

"Mengenai supervisi terhadap para guru dalam proses pembelajaran di dalam kelas adalah sebagai berikut: 1) masuk kelas, untuk mengamatai proses belajar dan mengajar dengan tujuan untuk mengetahui kelebihan dan kekurangan guru di dalam mengajar, 2) sambil jalan atau keliling kelas saya mengamati para guru yang sedang melakukan kegiatan belajar mengajar. Dengan cara yang kedua ini guru tidak merasa canggung dan saya bisa mengetahui kekurangan dan kelebihan mereka. Dari hasil pengamatan proses pembelajaran ini saya sedikit banyak mengetahui kelebihan dan kekurangan 
guru tersebut. Pada saat jam istirahat saya panggil ke kantor dengan ucapan selamat dan terima kasih telah mengajar dengan baik, dipertahankan dan terus ditingkatkan kepada guru yang menguasai dalam proses pembelajaran serta saya komunikasikan diajak bersama-sama untum membenahi kekurangan sekaligus menawarkan solusi yang berkenaan tentang metode mengajar dan pengelolaan kelas kepada guru yang kurang menguasai dalam proses belajarmengajar"

Dari hasil wawancara tersebut bisa kita lihat dengan jelas bahwa untuk mengetahui kinerja guru di kelas kepala madrasah selalu melakukan pengawasan atau supervisi langsung dengan cara keliling kelas untuk melihat guru, dan bahkan kepala madrasah masuk kelas untuk melihat secara langsung apa yang telah dilakukan oleh guru di kelasnya masing- masing. Dengan demikian peran kepala madrasah yang salah satunya adalah sebagai supervisor pembelajaran telah diterapkan oleh kepala madrasah di MTs Bahrul Ulum Rantau jaya ini dengan baik, dan hal ini akan berimplikasi terhadap peningkatan kinerja guru di madrasahtersebut.

Selain melakuakan supervisi pengajaran terhadap guru kepala madrasah juga berperan dalam proses pelaksanaan monitoring atau evaluasi terhadap hasil kerja semua staf yang ada di madrasah termasuk juga guru, dalam rangka tercapainya kualitas pendidikan yang bermutu dan mampu berdaya saing. Karena jika monitoring dan proses evaluasi seorang kepala madrasah ini lemah maka ini akan berdampak pada out put yang dihasilkan. Kegiatan monitoring atau evaluasi ini dilakukan untuk mengetahui apakah perencanaan madrasah yang telah disusun sebelumnya itu telah tercapaisesuai dengan tujuan yang telah dirumuskan atau tidak. Berkaitan dengan masalah monitoring ini berikut penuturan dari Bapak Supriadi S.Pd.I., M.Pd selaku kepala madrasah :

"Saya setiap hari ada kesempatan terus melakukan monitoring kinerja para guru dan karyawan. Kegiatan Monitoring ini saya lakukan yang gunanya untuk mengetahui apakah program yang direncanakan oleh para guru dan karyawan sudah terlaksana dengan baik apa belum Monitoring yang saya lakukan tiap hari mengecek daftar hadir guru dan karyawan setelah itu saya berkeliling untuk mengetahui kondisi kelas. Monitoring tiap satu minggu saya lakukan terhadap para waka. Sedangkan monitoring yang saya lakukan tiap satu bulan sekali untuk semua guru dan karyawan. Pada saat saya melakukan monitoring selalu saya menekankan untuk berhati-hati didalam melaksanakan kewajiban jangan sampai ceroboh dan para guru dan karyawan agar terus meningkatkan kinerja. Pada saat melakukan monitoring apabila ada guru ataupun karyawan belum bisa mencapai target yang sudah diprogramkan saya selaku kepala madrasah tidak serta merta menegur, namun saya lebih mengedepankan musyawarah.Saya menanyakan apa sebab sampai belum 
tercapai dan saya juga menanyakan apa akibat bila belum tercapai. Kemudian secara kekeluargaan kita memecahkan bersama-sama"

Dari penjelasan yang dipaparkan oleh kepala madrasah tersebut juga dapat dipahami bahwa pelaksanaan monitoring terhadap guru, para waka dan semua staf termasuk karyawan sekolah telah dilakukan secara kontinu dan terjadwal dengan baik oleh kepala madrasah. Hal ini dilakukan untuk menghindari terjadinya kesalahan atau kecerobohan yang bisa berpengaruh pada terhambatnya tujuan lembaga madrasah yang beliau pimpin. Jika ada personil madrasah yang masih kurang benar dalam menjalankan tugasnya beliau juga tidak segan-segan atau menegur dan memberi peringatan.

Dari hasil observasi yang peneliti lakukan, kepala MTsBahrul Ulum Rantau jaya sekarang ini mempunyai perhatian yang tinggi terhadap tugas- tugas yang harus dikerjakan, sesuai dengan rencana dan selanjutnya kepala madrasah memberi arahan tentang cara melakukan pekerjaan itu dan menyatu dengan guru dalam mengkomunikasikan tentang pekerjaan dan sasaran tugas yang akan dikerjakan.Adapun yang berkaitan dengan peran kepala madrasah dalam memberikan beban tugas yang sudah di programkan selama ini adalah sebagaimana yang telah dituturkan oleh Bapak Moh Hanapi S.Pd.I selaku waka kurikulum, sebagai berikut ini:

"Bapak kepala madrasah dalam memberikan beban tugas kepada kami sesuai dengan juknis yang ada dan kami tinggal menjalankannya sesuai dengan juknis melalui rapat. Setelah program di bebankan kepada kami Bapak Sama’i mendampingi dan memantau pekerjaan yang sedang kami kerjakan dan sekaligus memberi masukanyang menurut beliau ada kekurangan, dan sebagai bentuk kami melaksanakan program kami diwajibkan membuatlaporan (wawancara dengan WAKA)"

Berdasarkan hasil wawancara tersebut, menunjukkan bahwa kepala MTs Bahrul Ulum Rantau jaya sangat memperhatikan terhadap tugas dan tanggung jawabnya dalam memberi arahan dan binaan tentang cara melakukan pekerjaan yang dibebankan terhadap para guru, dan bahkan kepala madrasah selalu terdepan dalam memulai setiap aktivitasnya sebagai seorangpemimpin. Disamping itu kepala madrasah memberi penjelasan sesuai dengan juknis yang ada terhadap beban tugas yang akan dijalankan.

Untuk selanjutnya berkaitan juga dengan masalah peran kepala madrasah dalam upaya peningkatan guru di MTs Bahrul Ulum Rantau jaya ini, Bapak Supriadi M.Pd., juga menambahkan sebagaimana berikut di bawah ini :

"Saya diawal menjabat di madrasah ini, saya menginginkan terlaksananya proses belajar mengajar yang sesuai dengan standart. Pengaturan lingkungan fisik madrasah yang memadai antara lain mencangkup ruang kerja yang kondusif, ruang belajar, ruang perpustakaan, ruang laboraturium. Prioritas 
pertama: Kondisi fisik gedung madrasah dan peralatan yang mendukungnya. Kondsi fisik yang akan saya prioritaskan adalah penambahan lokal, pagar, plengseng, melanjutkan pembangunan mushola, pembangunan lapangan basket, peralatan band, pembangunan ruang santai, taman dan sekaligus melengkapi LCD. Disamping itu saya berusaha menciptakan suasana kerja yang harmonis dengan cara memecahkan sesuatu permasalahan dengan cara bermusyawarah. Dengan bermusyawarah tersebut para guru dan staf merasa untuk dihargai dan dihormati pendapatnya. Saya juga berusaha untuk menanamkan disiplin kepada para guru dan staf. Hal ini seperti yang saya katakan tadi saya lebih awal masuk madrasah ini dan juga alhamdulillah dimadrasah ini sudah dilaksanakan absensi sistem cek clock yaitu para guru dan karyawan yang datang awal, terlambat dan tidak masuk akan ketahuan. Hasil dari absensi cek clock akan disampaikan dan diinformasikan pada saat rapat"

Dari pernyataan tersebut di atas telah memberi gambaran kepada kita bahwa peran Bapak Supriadi M.Pd., selaku kepala madrasah dalam meningkatkan guru di MTs Bahrul Ulum Rantau Jaya ini juga memikirkan tentang kelancaran proses belajar mengajar bagi guru yakni dengan menambah dan meningkatkan jumlah sarana dan prasarana madrasah termasuk melengkapi media pembelajaran agar paragurutermotivasi dalam menjalankan proses belajar mengajar dan pembelajaran yang dilakukan bisa lebih menyenangkan dan berkualitas. Disamping itu kepala madrasah juga menekankan agar semua warga yang ada di madrasah selalu berdisiplin dalam semua hal, dan ini sudah diterapkan lebih dulu oleh kepala madrasah, beliau selalu datang lebih awal dan tepat waktu dan ini memotivasi para guru dan para staf yang lain untuk mengikuti jejak kepala madrasah tersebut.

Di samping itu berdasarkan hasil wawancara di atas untuk meningkatkan kinerja guru juga tidak lepas dari usaha melengkapi sarana dan prasarana pembelajaran termasuk media. Karena dengan perlengkapan yang memadai maka guru bisa leluasa untuk menggunakannya sehingga proses pembelajaran akan lebih menyenangkan.Untuk berikutnya dalam upaya meningkatkan kinerja guru di MTs Bahrul Ulum ini Bapak kepala madrasah juga menerapkan prinsip penghargaan, walaupun tidak selalu berupa hadiah fisik bagi mereka yang berprestasi, dan hukuman bagi mereka yang kurang bertanggung jawab terhadap tugas masing-masing.

\section{Strategi Kepala Madrasah dalam Meningkatkan Etos Kerja Guru}

Adapun berkaitan dengan masalah salah satu strategi yang ditempuh oleh kepala MTs Bahrul Ulum Rantau Jaya dalam upaya meningkatkan guru adalah dengan cara membangkitkan semangat kinerja para guru sebagaimana hasil penuturan beliau kepada peneliti: 
"Dalam rangka membangkitkan semangat para guru, disetiap rapat saya selalu mengingatkan dan menekankan tentang nilai perjuangan, menyadarkan para guru dengan perjuangan. Jadi penekanan pertama kali adalah perjuangan karena dengan nilai-nilai perjuangan kita akan mendapatkan dua hal yang kita harapkan. Pertama adalah pahala dihadapan Allah dan yang kedua pahala didunia yang berupa gaji. Pahala di dunia betul-betul wajib disyukuri karena para guru MTs Bahrul Ulum Rantau Jaya punya gaji lebih bila dibandingkan dengan guru di lembaga-lembaga swasta. Sekaligus juga mengingatkan kepada para guru bahwa tugas kita adalah sebagai abdi masyarakat maka harus siap melayani masyarakat, dan saya memberikan contoh semampu saya kepada para guru. Jadi tidak serta merta guru langsung disuruh. Saya mengedepankan ibda' binafsi maksudnya saya memberi contoh semampu saya. Dengan cara ini saya tidak langsung menyuruh mereka untuk bekerja. Namun, saya memberi contoh lebih dahulu. Dan juga saya selalu mengingatkan bahwa madrasah yang kita cintai ini adalah milik kita bersama. Madrasah tidak bisa maju apabila kita tidak bekerja bersama-sama. Kita berfikir dan bekerja bersama-sama demi kemajuan madrasah ini. Kita tidak boleh ada yang merasa pinter, semua sama. Apabila terdapat kendala di madrasah kita pecahkan bersama-sama

Dari hasil wawancara tersebut, menandakan bahwa kepala madrasah berusaha mempengaruhi para guru dan karyawan untuk menimbulkan semangat terhadap pekerjaan dan komitmen terhadap sasaran tugas. Dan membantu serta memberi contoh sesuai dengan harapan dan rencana yang telah dibuat.Selain yang telah dituturkan oleh kepala madrasah di atas, ternyata beliau juga menambahkan dalam kaitannya dengan strategi yang beliau tempuh dalam upaya peningkatan kinerja guru, tutur beliau kemudian adalah sebagaimana berikut di bawah ini :

Begini pak, dimana ada kesempatan saya selalu mengingatkan kepada para guru dan karyawan baik pada waktu rapat maupun ketika ngobrol untuk selalu ingat bahwa Kita tidak hanya mentransver pelajaran kepada anak didik saja namun kita adalah sebagai sosok guru yang tentunya patut digugu dan ditiru. Kita memberi contoh yang baik kepada peserta didik. Disamping itu juga untuk menumbuhkan motivasi agar kinerja guru meningkat dengan melalui berbagai upaya yaitu memberikan penghargaan pada guru yang telah berprestasi. Penghargaai ini kami lakukan ada dua bentuk yaitu ucapan selamat terima kasih Bapak/Ibu telah berhasil mohon terus dipertahankan danterus ditingkatkan. Sedangkan bentuk yang kedua kami beri sertifikat dan hadiah baik berupa benda atau uang, pemberian sertifikat dan hadiah ini kami berikan ketika rapat penerimaan raport semester I dan kenaikan kelas"

"Hal ini dengan maksud dan tujuan untuk memotivasi agar lebih giat dalam menjalankan tugas dan kewajiban, juga untuk dibuat contoh oleh guru-guru 
lain yang kebetulan belum berhasil meraih prestasi. Strategi yang kedua kami lakukakan adalah memberikan teguran secara langsung apabila guru melanggar peraturan madrasah dengan cara guru tersebut saya panggil keruang saya (ruang kepala madrasah). Hal ini dengan maksud agar tidak mengulangi kesalahan yang diperbuat. Atau kalau hal ini kebetulan saya ada keperluan mendadak dan ada salah satu guru yang berbuat kesalahan saya memerintahkan kepada waka kurikulum untuk mengingatkan secara langsung. Dan strategi yang ketiga kami lakukan adalah strategi menerima saran. Bapak ketahui bahwa lembaga ini menjadi maju dan mundur adalah usaha kita bersama, saya tidak mau dikatakan yang paling pinter, paling pandai atau yang lainnya. Madrasah ini adalah milik kita bersama dan perlu kita kembangkan bersama sehingga maju dan mundurnya madrasah adalah tanggung jawab kita bersama. Dengan demikian saya butuh saran dan dukungan dari semua pihak lebih-lebih dari para guru dan staf yang lainnya. Pak Ahmad, yang tak kalah pentingnya strategi berikutnya adalah keteladanan, memberi contoh kepada para guru dan staf hal ini saya buktikan setiap pagi saya lebih awal datang dimadrasah ini dan pulang paling akhir kecuali ada acara mendadak”

Dari beberapa uraian di atas, dapat kita tarik kesimpulan ada beberapa strategi yang digunakan oleh beliau dalam meningkatkan Etos Kerja guru MTs Bahrul Ulum Rantau jaya ini, yang diantaranya adalah strategi memberi penghargaan bagi yang berprestasi, strategi teguran secara langsung bagi guru yang melakukan kesalahan, strategi menerima saran dan strategi keteladanan. Disamping itu kepala madrasah juga selalu mengingatkan kepada guru bahwa tugas kita sebagai guru adalah bukan hanya transfer ilmu saja kepada anak didik ( mengajar ) akan tetapi yang lebih penting lagi adalah transfer nilai ( mendidik ) dan ini yang sangat sulit. Oleh karena itu untuk bisa melakukan proses mendidik atau transfer nilai maka guruharusmempunyai integritas moral yang utuh atau kompetensi kepribadian seorang guru harus benar-benar bisa diterapkan.

Dari beberapa uraian yang tersebut di atas, dapat kita pahami bersama bahwa strategi kepala madrasah dalam meningkatkan semangat para guru ditempuh dengan beberapa cara antara lain ; melalui pelatihan atau workshop agar kompetensinya bisa meningkat, karena jika semua guru sudah berkompeten pada bidang masing-masing maka nya juga tidak sembarangan atau dengan kata lain seorang guru akan lebih bersemangat dalam bekerja jika ia memiliki kompetensi pada bidang yang ia tekuni itu. Oleh karena itu program pelatihan, workshop maupun kerja sama dengan lembaga lain selalu dilakukan oleh kepala sekolah MTs bahrul Ulum Rantau jaya dalam upaya meningkatkan kinerjaguru.

Selain itu saya juga selalu menghimbau kepada seluruh karyawan termasuk guru PN maupun sertifikasi untuk selalu mensyukuri atas rezeki yang telah diberikan oleh Allah, kembali saya ingatkan kepada para guru kita punya nilai 
lebih bila dibandingkan dengan guru-guru swasta. Saya selalu mengingatkan untuk pandai mensyukuri atas rezeki lebih yang dberikan kepada para guru PN lebih-lebih guru PN yang sudah sertifikasi.

"Pemberian kesejahteraan atau gaji para guru dan karyawan di luar gaji pokok ternyata juga dilakukan oleh kepala MTs Bahrul Ulum Rantau Jaya ini yang tentunya dengan melihat kondisi lembaga atau disesuaikan dengan kemampuan dan kondisi keuangan yang ada. Tapi yang jelas reward yang diterima oleh para guru dan karyawan di MTs Baharul Ulum Rantau Jaya ini masihlebih besar dibanding dengan reward yang bisanya diberikan di sekolahsekolah swasta lain di wilayah Tumpang. Oleh karena itu ternyata dengan cara seperti ini juga bisa menambah semangat para guru untuk lebih meningkatkan kinerjanya di sekolah"

Kemudian langkah berikutnya yang ditempuh oleh kepala madrasah dalam upaya meningkatkan guru adalah dengan memberi motivasi terhadap para guru agar lebih giat dalam bekerja. Hal ini sebagaimana yang telah diungkapkan oleh Bapak Drs. Supriadi M.Pd., selaku kepala madrasah kepada penulis berikut ini :

"Dimana ada kesempatan saya selalu mengingatkan kepada para guru dan karyawan untuk selalu ingat bahwa kita di madrasah ini berjuang sekaligus sebagai abdi negara dan masyarakat yang merupakan tugas mulia yang harus kita emban. Tentunya kita harus selalu meningkatkan kinerja kita yang sudah diamanatkan kepada kita. Kita tidak hanya mentransver pelajaran kepada anak didik saja namun kita adalah sebagai sosok guru yang tentunya patut digugu dan ditiru. Kita memberi contoh yang baik kepada peserta didik. Disamping itu juga untuk menumbuhkan motivasi agar guru meningkat dengan melalui pengaturan lingkungan fisik, pengaturan susana kerja, disiplin, dorongan, penghargaan secara efektif dan penyediaan dana sarana sumber belajar melalui pengembangan pusat sumber belajar (PSB)"

Dorongan atau motivasi para guru di madrasah ini timbul semangat untuk meningkatkan kinerjanya menurut saya timbul dari diri pribadi para guru. Sesuai dengan komitmen kita dari awal bahwa kita masuk dimadrasah ini niat kita untuk berjuang dan merupakan abdi negara. Walaupun tidak ada unsur dorongan dari luar kita sudah berusa untuk yang lebih baik. Sedangkan bentuk dorongan atau bentuk motivasi dari luar menurut saya untuk meningkatkan kinerja guru, meningkatkan kompetensi para guru dengan mengikutkan diklat diluar baik agama/umum yang nantinya sosialisasikan hasil pelatihan kepada guru-guru yang lain (se-kkm MTs Muratara) dan untuk meningkatkan kualitas pengajaran berkelanjutan dibina oleh tim konsultan pendidikan berpengalaman, dari Dinas Pendidikan Kab. Muratara. 


\section{Dampak Strategi Kepala MTs Rantau Jaya dalam Meningkatkan Etos KerjaGuru}

Besar kecilnya minat guru terhadap tugas yang akan mempengaruhi kadar atau Etos Kerja guru mengembangkan di madrasah. Minat dan kemampuan terhadap suatu pekerjaan berpengaruh pula terhadap moral kerja guru.Tanggung jawab guru dalam melaksanakan tugas di madrasah, ditandai dengan upaya tidak segera puas atas hasil yang dicapainya.

Dapat dikatakan bahwa kadar kinerja yang dimiliki guru dalam melaksanakan tugas dimadrasah tergantung banyak sedikitnya bebantugas yang menjadi tanggung jawabnya yang harus dilaksanakan guru sehari-hari dan bagaimana cara menyelesaikan tugas ini yang ditekankan pada tugas mengajar, membimbing dan melaksanakan administrasi madrasah.Di bawah ini adalah hasil wawancara peneliti dengan guru Mts Bahrul Ulum Rantau Jaya yaitu bapak Taufiq Efendi S.Pd.I, tentang dampak strategi kepala madrasah terhadap meningkatkan kinerja guru di MTs Bahrul Ulum Rantau jaya dalam kemampuan mengelola kelas adalah sebagaimana berikut ini :

"Kalau diprosentase paling tidak 80\% kompetensi guru-guru menjadi lebih bagus, terutama dalam hal kemampuan mengelola kelas, kemudian semua guru dapat aktif dalam pembuatan LKS serta pembuatan sosal ujian yang memang dalam madrasai ini betul-betul menjadi center atau aktor utama dalam pembuatan soal skala kabupaten untuk rujukan bagi guru-guru di sekolah-sekolah lain terutama sekelompok kkmnya"

Dari paparan di atas, jelas menunjukkan kepada kita bahwa ada dampak positif dari strategi kepemimpinan yang telah diterapkan oleh kepala madrasah terhadap peningkatkan kinerja guru di MTs Bahrul Ulum Rantau jaya yakni terjadi peningkatan kualitas dari para guru terutama dalam mengelola kelas dengan menyediakan suasana yang kondusif untuk berlangsungnya proses pembelajaran yang efektif danefisien.Untuk selanjutnya berkaitan dengan dampak strategi kepemimpinan kepala madrasah dalam hal kemampuan dalam penataan iklim kelas sebagaimana hasil penuturan dari bapak Taufiq Efendi S.Pd.I selaku guru berikut ini:

"Mengenai dampak dari strategi kepemimpinan yang telah diterapkan oleh beliau di madrasah ini yang terutama berkaitan dengan sistem penataan iklim kelas, ternyata siswa Mts Bahrul Ulum mendapat nilai yang sangat memuaskan, salah satu sebabnya adalah penggunaan tehnologi berbasis IT telah diprogramkan sehingga guru-guru semangat untuk selalu up date strategi pembelajaran yang menggunakan strategi pembelajaran berbasis IT, dengan demikian iklim dikelas semakin kondusif dan menyenangkan, sehingga anak atau siswa lebih mudah menguasi mata pelajaran. Kemudian yang tidak kalah pentingnya adalah dari program kelas unggulan semakin banyak peminat dari orang tua atau peserta didik khusus yang ekonomi menengah 
keatas diwilayah kota untuk masuk kelembaga ini bahkan tahun ini siswa melebihi target yang telahditentukan"

Dari semua hasil wawancara tersebut di atas, ternyata dampak strategi kepemimpinan yang telah diterapkan oleh kepala madrasah dalam meningkatkan Etos Kerja guru di MTs Bahrul Ulum Rantau Jaya menunjukkan adanya perubahan yang cukup memuaskan baik dari sisi pengelolaan kelas, system pembelajaran maupun penataan iklim kelas yang kondusif, semuanya ini akan member pengaruh yang positif terhadap keberhasilan proses dan hasil belajar pesertadidik.

\section{Strategi Kepala Madrasah dalam Meningkatkan Etos Kerja Guru}

Dari diskripsi hasil penelitian di atas maka dapat penulis simpulkan beberapa temuan penelitian yang berkaitan dengan strategi kepala madrasah dalam meningkatkan guru di MTs Bahrul Ulum Rantau Jaya adalah sebagaiberikut:membangkitkan semangat kinerja para guru dengan cara menumbuhkan rasa memiliki terhadap lembaga sehingga tumbuh rasa tanggung jawab yang tinggi dan mengingatkan akan nilai-nilai perjuangan bagi seorang guru.Kerja sama dengan lembaga lain dalam mengikutkan workshop, pelatihan untuk meningkatkan kompetensi yang akhirnya kinerja bisa meningkat. Memberikan motivasi kepada guru agar lebih giat dalam bekerja dengan mengingatkan bahwa tugas guru bukan hanya transfer ilmu tapi juga transfernilai. Bentuk motivasi adalah secara instrinsik danekstrinsik. Melakukan pengembangan dan pembimbingan terhadap para guru dengan cara mendatangkan tim ahli pada bidangnya untuk mengadakan pembinaan. Melakukan komunikasi persuasif dengan paraguru. Memberikan penghargaan pada guru yang berprestasi dan Memberikan kesejahteraan di luar gaji pokok yang disesuaikan dengan kemampuan lembaga Strategi memberi perintah sesuai dengan tupoksi dan strategi menegur Strategi menerima saran dan strategi menciptakan disiplin kelompok

\section{Dampak Strategi Kepala Madrasah dalam Meningkatkan Etos KerjaGuru}

Kemapuan mengelolakelas meliputi; a) kalau diprosentase paling tidak $80 \%$ kompetensi guru-guru menjadi lebih bagus, terutama dalam hal kemampuan mengelola kelas, b) semua guru dapat aktif dalam pembuatan LKS serta pembuatan sosal ujian yang memang dalam madrasai ini betul-betul menjadi center atau aktor utama dalam pembuatan soal skalakabupaten untuk rujukan bagi guru-guru di sekolah-sekolah lain terutama sekelompokkkmnya.

Kemampuan dalampengajaran meliputi; a) dari kontroling tersebut guruguru hampir $100 \%$ dapat membuat administrasi pembelajaran sesuai target yang diinginkan terlebih guru-guru yang sudahtersertifikasi, b) dari pendisiplinan jam kerja guru-guru betul masuk setiap hari pada jam 06.30 pulang jam 02.00 
walaupun tidak ada jam mengajar, c) dari pemberian reward guru-guru bertambah semangat meningkatkan nya, walaupun tingkat kesemangatan dari reward ini tidak mencapai 50\%dampaknya, d) dari adanya sangsi moral guru-guru takut meninggalkan tugas atau melanggar peraturan madrasah walaupun cuma sekedar tidur dimejanya, e) dari keharusan mempunyai laptop sendiri, guru-guru efektif dalam pembuatan perangkat pembelajaran serta proses evaluasi siswa dan perencanaan pemb elajaran sesuai dengan target yangditentukan, f) dari pelatihan khusus waka kurikulum para guru bisa mandiri membuat perangkat pembelajaran sekaligus tehnikevaluasi, g) dari membuat program tahfidz Al-Qur'an sebagian siswa ada yang sudah mengikuti program hafalAl-Qur'an.

Kemampuan dalam penataan iklmkelas meliputi; a) siswa Mts Bahrul Ulum mendapat nilai UNAS yang memuaskan artinya melampaui batas standart minimal yang telah ditentukanlembaga, b) dari program kelas unggulan semakin banyak peminat dari orang tua atau peserta didik khusus yang ekonomi menengah keastas diwilayah kota untuk masuk kelembaga iini bahkan tahun ini siswa melebihi target yang telahditentukan, c) sari penggunaan tehnologi berbasis IT guru-guru semangat untuk selalu up date strategi pembelajaran yang menggunakan strategi pembelajaran berbasisIT.Anak atau siswa lebih mudah menguasai mata pelajaran

\section{SIMPULAN}

Gambaran Kepemimpinan Kepala Mts Bahrul Ulum berperan aktif dalam upayameningkatkan etos kerja guru yaitu dengan Menjalin hubungan yang harmonis terhadap sesama pengajar (para guru), Memberikan kesejahteraan kepada para guru yang memadahi, Mengkontrol dan mengevaluasi guru dalam menjalankan tugas mereka sehingga dapat merubah pola pikir dalam membangun karakter guru.Gambaran Etos Kerja Guru di Mts Bahrul Ulum menumbuhkan motivasi yang tinggi dalam melaksanakan Program KBM, sehingga para guru turut membangun Mts Bahrul Ulum menjadi terdepan sesuai dengan visi dan misinya.

\section{DAFTAR PUSTAKA}

Mulyasa, E. (2005). Menjadi Kepala Madrasah Professional (Dalam Konteks Menyukseskan MBS Dan KBK ). Bandung: Remaja Rosda Karya

Soekarto, I. (1993). Mengantar Bagaimana Memimpin Madrasah yang Baik. Jakarta: Ghalia Indonesia

Soewadji, L. (1988). Kepala Madrasah dan Tanggung Jawabnya. Yogyakarta: Kanisius

Hendiyat, S., \& Wasty, S. (1984). Kepemimpinan dan Supervisi Pendidikan. Jakarta: Bina Aksara

Uzer, U. (1990).Menjadi Guru Professional. Bandung: Remaja Karya

Matthew, B. M., \& Huberman, H. (1992). Analisis Data Kualitatif : buku sumber tentang metode metode baru, Tjetjep Rohidi ( terj.). jakarta: Ul press 